\title{
RANCANG BANGUN APLIKASI ANTRIAN POLIKLINIK BERBASIS MOBILE
}

\author{
Rizal Arif Zulfikar ${ }^{1}$, Ahmad Afif Supianto ${ }^{2}$ \\ ${ }^{1,2}$ Fakultas Ilmu Komputer, Universitas Brawijaya \\ Email: ${ }^{1}$ rizal0x97@gmail.com, ${ }^{2}$ afif.supianto@ub.ac.id
}

(Naskah masuk: 28 Juni 2018, diterima untuk diterbitkan: 08 Agustus 2018)

\begin{abstract}
Abstrak
Antrian konvensional sudah menjadi polemik yang umum di masyarakat. Lamanya proses dan waktu tunggu antrian sangat mengganggu aktivitas sehari-hari. Pada instansi kesehatan seperti rumah sakit dan poliklinik, dimana pasien juga diharuskan mengantri, dapat berpengaruh pada kondisi pasien. Sistem pendaftaran online yang ada hanya menyediakan pengambilan nomor antrian, namun untuk proses menunggu antrian masih harus datang ke lokasi. Sistem yang ditawarkan memiliki kelebihan pada pilihan variasi jadwal poliklinik, dan pemberian informasi antrian yang sedang berjalan. Pada penelitian ini membahas tentang perancangan dan pengembangan sistem antrian poliklinik yang berbasis pada mobile phone, sehingga pengguna dapat mengakses sistem kapanpun dan dimanapun. Perancangan menggunakna metode MVC untuk memisahkan antara data dan tampilan serta cara pemrosesannya. Pengembangan aplikasi menggunakan hybrid mobile web framework yang dapat digunakan untuk pengembangan multiplatform. Pengujian sitem menggunakan White Box, Black Box, dan Usability Testing telah menunjukkan bahwa struktur dan hasil desain sistem dapat diimplementasikan dengan baik, sehingga sistem dapat berjalan sesuai kebutuhan.
\end{abstract}

Kata kunci: Antrian Mobile, Antrian Online, Poliklinik, MVC, White Box Testing

\section{DESIGN AND DEVELOPMENT OF MOBILE-BASED POLYCLINIC QUEUE APPLICATION}

\begin{abstract}
The conventional queue has become a common polemic in society. The length of process and waiting time of the queue is very disturbing on daily activities. In health agencies such as hospitals and polyclinics, where patients are also required to queue up, may affect the patient's condition. Existing online registration system only provides queue number retrieval, but for the waiting process the queue still has to come to the location. The offered system has advantages over the choice of polyclinic schedule variations, and the provision of queue information is running. This research discusses the design and development of polyclinic queuing system based on mobile phone, so that users can access the system anytime and anywhere. The design uses MVC method to separate data and display and how to process it. Application development using hybrid mobile web framework that can be used for multiplatform development. System validation method is using White Box, Black Box, and Usability Testing has shown that the structure and results of system design can be implemented well, so the system can run as needed.
\end{abstract}

Keywords: Mobile Queue, Online Queue, Polyclinic, MVC, White Box Testing.

\section{PENDAHULUAN}

Pada era sekarang ini hampir semua orang menuntut pelayanan publik untuk semakin efektif dan efisien ketika berbicara tentang layanan. Termasuk didalamnya adalah pelayanan kesehatan pada rumah sakit/poliklinik. Rumah sakit/poliklinik merupakan instansi pelayanan kesehatan publik yang sangat vital dan memiliki peran sangat penting ditengah masyarakat, dimana mereka adalah pengguna layanan kesehatan dan tentunya harus mendapatkan pelayanan yang prima karena berkaitan erat dengan masalah kesehatan.

Setiap hari ketika berkunjung ke rumah sakit/poliklinik masyarakat sering menjumpai calon pasien yang ingin berobat ramai didepan loket antrian. Memberlakukan antrian hampir di berlakukan di setiap rumah sakit/poliklinik ,hal ini merupakan inisiatif manajemen rumah sakit untuk tetap menjaga ketertiban, Akan tetapi dominan dari system sistem antrian berupa system secara manual dimana petugas pendaftaran memanggil pasien secara lisan, dengan menggunakan pengeras suara. 
Sistem antrian poliklinik secara manual selama ini tentunya dinilai berjalan kurang efektif dan efisien. Karena dengan cara konvensional tersebut memaksa calon pasien harus mendaftar dengan cara mendatangi langsung rumah sakit/poliklinik untuk mengambil nomor antrian di bagian pendaftaran. Sistem ini menyebabkan ketidaknyamanan terhadap calon pasien karena mereka harus menunggu lama untuk dipanggil sesuai dengan urutan nomor antrian dan terkadang juga jam operasional rumah sakit/poliklinik tidak mencukupinya jumlah nomor antrian dengan jumlah calon pasien yang akan berobat pada hari itu.

Penelitian oleh Laeliyah (2017), Torry (2016), dan Bustani (2015) menyatakan bahwa waktu tunggu antrian pada sistem konvensional sangat berpengaruh pada tingkat kepuasan pelayanan pasien. Berdasarkan hal tersebut, tak dipungkiri lagi bahwa sistem antrian manual cenderung menimbulkan ketidaknyamanan bagi calon pasien yang akan berobat. Oleh karena itu, dibuatlah sebuah rancangan dan implementasi dari suatu sistem antrian yang membantu antrian untuk menjadi terorganisir dan menyenangkan dan dapat di akses dari mobile phone.

Terdapat beberapa penelitian mengenai solusi antrian yang telah dilakukan. Sistem yang digunakan mulai meninggalkan sistem konvensional, yaitu mendatangi lokasi antrian dan mengambil nomor antrian. Namun beberapa masih melakukan optimasi pada sistem konvensional tersebut. Pada penelitian oleh Kundang K Juman, 2012, menggunakan Aplikasi desktop komputer (offline) untuk meningkatkan efektifitas pelayanan. Sedangkan penelitian lain menggunakan aplikasi yang terhubung dengan jaringan sehingga akses pendaftaran dapat dilakukan secara online, salah satunya adalah penelitian oleh Bambang Sutikno, 2017. Beberapa penelitian mengunakan teknologi pada mobile phone sebagai media pendaftaran online, ada yang menggunakan media sms untuk managemen antrian (Syed Suhail D, dkk. 2018), ada pula yang menggunakan tenologi Near Field Communication atau NFC untuk check in antrian (Yeo Symey, dkk. 2018). Sebagian besar menggunakan aplikasi dengan platform android karena tergolong mudah dalam pengembangan.

Pada penelitian oleh Sukma Bahrul Aziz, Tengku A. Riza, dan Rohmat Tulloh dari Universitas Telkom dengan judul "perancangan dan implementasi aplikasi sistem antrian untuk pasien pada dokter umum berbasis android dan sms gateway" adalah penelitian yang mendekati dengan pengembangan yang ditawarkan pada penelitian ini. Namun pengembangan pada penelitian Sukma, dkk, dilakukan pada native android sehingga untuk pasien yang tidak menggunakan android, notifikasi akan disediakan menggunakan fitur sms gateway. Pada penelitian tersebut, aplikasi mobile hanya dapat digunakan oleh pasien, dan fokus hanya pada fitur pemesanan antrian. Jika aplikasi jarang digunakan maka akan mengurangi daya tarik pasien sehingga aplikasi akan mudah ditinggalkan. Pada dashboard hanya menampilkan nomor antrian pasien dan nomor yang sedang dilayani. Antrian juga tidak memiliki pilihan jenis antrian dan jadwal antrian.

Aplikasi mobile phone terutama android, memiliki beberapa apliaksi antrian untuk bidang kesehatan. Beberapa diantaranya adalah Aplikasi pendaftaran online Bakti Husada, Registrasi Pasien Rumah Sakit, Rumah Sakit JIH Jogjakarta, Pendaftaran pasien Puskesmas, Antrian Online RSIA, AntrianQ, eHealth Surabaya, AntriApp, dan lainnya. Aplikasi antrian juga hanya terfokus pada pendaftaran antrian. Sehingga setelah melakukan pendaftaran, aplikasi tidak terlalu dibutuhkan lagi. Sedangakan calon pasien masih membutuhkan informasi lain seperti info antrian yang sedang berjalan, atau notifikasi untuk pengingat jadwal antrian (untuk notifikasi beberapa aplikasi telah menyediakan). Sebagian besar aplikasi juga hanya menyediakan antrian untuk hari-H pemeriksaan. Hal ini kurang sesuai jika menemukan kasus dimana saat calon pasien ingin melakukan pemeriksaan dan ternyata antrian saat itu terlalu panjang atau bahkan penuh, maka secara otomatis mereka akan mengubah jadwal pemerikasaan ke hari lain saat itu juga.

Rancangan yang diajukan memiliki kelebihan pada metode pengembangannya yaitu menggunakan hybrid app framework. Dimana pengembangan dapat dilakukan hanya sekali untuk multiplatform, contohnya android, iphone, windows phone, web app, dan lainnya. Hasil aplikasi dari rancangan yang diajukan juga dapat digunakan oleh dokter dan karyawan untuk berdikusi melalui fitur chat dan berbagi informasi melalui fitur berita. Aplikasi juga menyediakan pencarian dokter dan jadwal poliklinik yang sesuai dengan keinginan pasien dengan pilihan waktu yang variatif (tidak terikat pada pendaftaran pada hari yang sama dengan pemeriksaan). Fitur lainnya dapat digunakan untuk menambah daya tarik pasien agar dapat terus menggunakan aplikasi, sehingga saat diperlukan dapat digunakan secara langsung tanpa harus memasang ulang aplikasi.

\section{PERANCANGAN APLIKASI MOBILE}

\subsection{Ionic Framework}

Aplikasi Mobile dibuat menggunakan framework ionic v1. Ionic adalah sebuah framewok aplikasi mobile berbasis HTML5 yang dapat digunakan untuk mengembangkan apikasi mobile dengan teknologi web seperti HTML, CSS, dan Javascript. Dengan menggunakan Ionic, para developer web bisa membuat aplikasi lintas platform seperti untuk Android dan iOS. Dengan menggunakan Ionic, para developer web tidak perlu belajar bahasa pemrograman Java, Objective C, atau $\mathrm{C \#}$ untuk membuat aplikasi mobile karena mereka 
cukup menggunakan ilmu mereka di bahasa pemrograman web.

Ionic mempunyai kelebihan diantaranya bersifat open source dan juga menggunakan teknologi web terbaru. Ionic juga menggunakan Angular JS untuk implementasi logikanya. Kabarnya, dengan menggunakan Angular JS aplikasi yang dibuat menggunakan Ionic akan dapat berjalan sangat cepat seperti halnya aplikasi native.

\subsection{Sitemap Aplikasi}

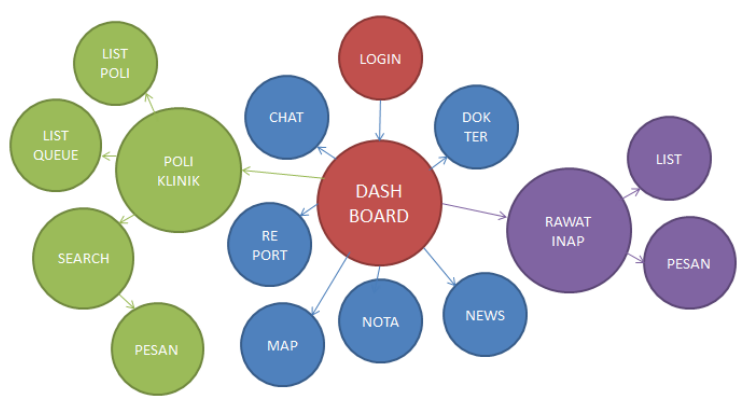

Gambar 1. Sitemap mobile apps.

Gambar 1 menampilkan pengelompokan fungsi pada rancangan yang ditawarkan. Aplikasi utama yang ditonjolkan dalam aplikasi adalah Antrian poliklinik. Sedangkan untuk fungsi lain adalah sebagai pendukung aplikasi. Halaman awal pada aplikasi adalah halaman login. Pada halaman login user akan diberikan form login berisi username dan password. Keduanya dapat diperoleh setelah melakukan pendaftaran di poliklinik terkait. Kemudian setelah login akan diarahkan pada halaman dashboard. Pada halaman dashboard ini terdapat 9 menu yaitu poliklinik, rawat inap, dokter, chat, report, map, nota, news, dan info. Untuk keluar atau logout user dapat melakukannya melalui menu setting profil.

\subsection{Poliklinik}

Aplikasi mobile memiliki tujuan utama menu poliklinik adalah melakukan pendaftaran antrian oleh calon pasien. Gambar 2 menampilkan alur kerja pendaftaran yang ditawarkan. Pada halaman awal, ditampilkan list poliklinik sehingga pengguna dapat memilih poliklinik yang akan dikunjungi. Setelah pengguna memilih poliklinik, akan ditampilkan form tanggal dan jadwal yang tersedia setiap minggu nya, jadwal ini dapat digunkan untuk menentukan tanggal yang sesuai pada hari yang diinginkan. Setelah tanggal dimasukkan, ditampilkan kuota maksimal pelayanan dalam satu jadwal, juga ditampilkan banyak user yang telah mendaftar pada jadwal tersebut sebelumnya. Sehingga dapat dilihat apakah kuota telah penuh atau tidak. Jika penuh maka pengguna disarankan untuk memilih jadwal lainnya.

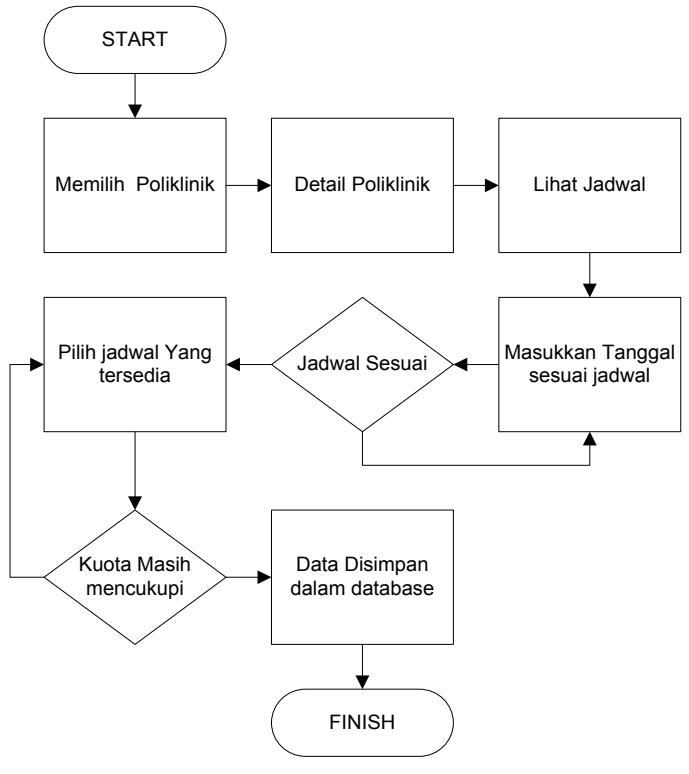

Gambar 2. Flow Diagram Pendaftaran Antrian.

Pada Gambar 3, Aktor pada sistem terdiri dari pasien, dokter, dan staff. Pasien dalam hal ini juga dapat disebut calon pasien, pengguna, atau anggota poliklinik. Setiap anggota dapat menggunakan fungsi login, akses pada halaman dashboard, melihat list poliklinik, dan melihat antrian. Hanya pasien yang dapat melakukan pendaftaran antrian pada sistem.

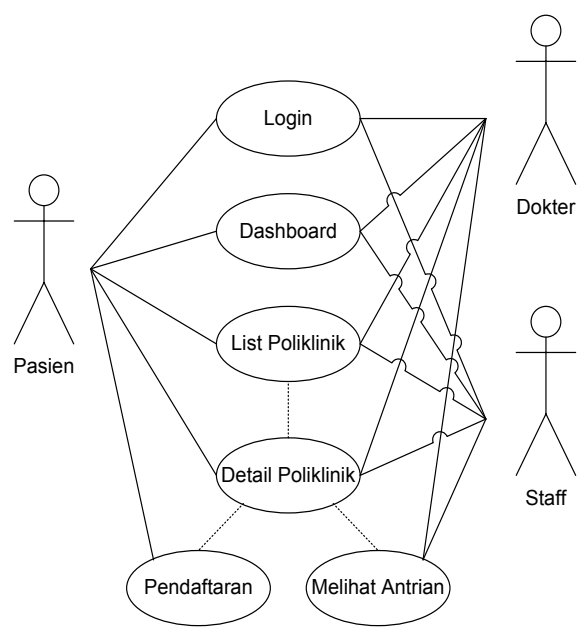

Gambar 3. Use Case Diagram Poliklinik.

Aktivitas pada proses antrian dapat dilihat pada Gambar 4. Aktivitas keseluruhan dilakukan oleh ketiga aktor. User fokus pada pendaftaran antrian dan melihat informasi antrian. Staff melakukan manajemen data poliklinik dan data antrian. Dokter menentukan jadwal praktek dan proses pengobatan pasien. 


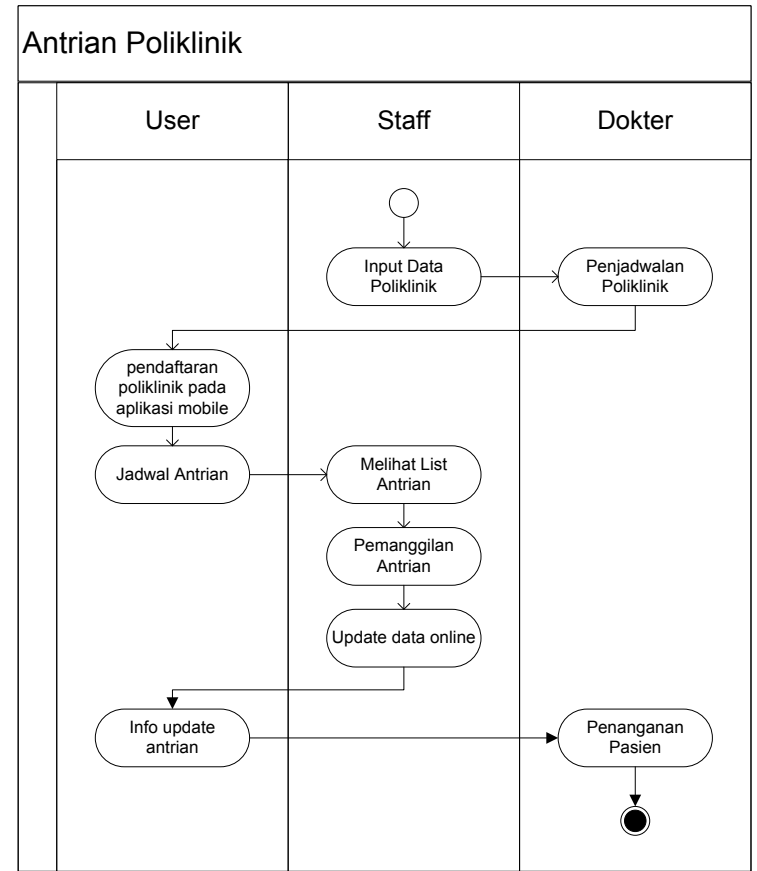

Gambar 4. Activity Diagram Antrian.

\subsection{Fasilitas Pendukung}

Fasilitas pendukung adalah fungsi lain selain fungsi utama sistem yaitu antrian poliklinik. Tujuan utama adalah untuk memberikan keterikatan lebih pada pengguna. Pada Gambar 5 adalah menu yang terdapat pada aplikasi. Pada menu terdapat fitur utama dan semua fitur pendukung.

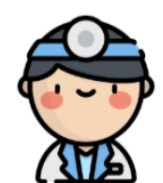

Dokter

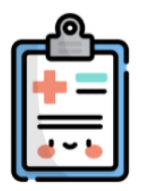

Report

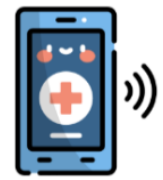

Chat

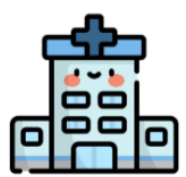

Poliklinik

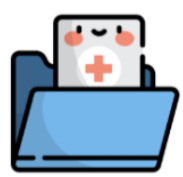

Nota

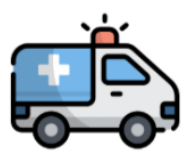

Penqumuman

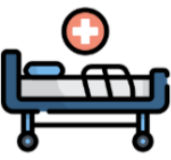

Rawat Inap

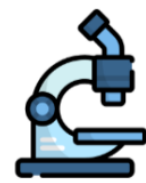

Map

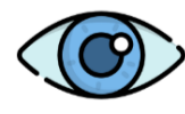

Info
Gambar 5. Menu Dashboard.

Hak akses pasien pada fitur dalam aplikasi mencakup smua aspek, dikarenakan memang target aplikasi ditujukan untuk pasien. Namun untuk dokter dan staff masih dapat menggunakan beberapa fitur untuk berkomunikasi dengan pasien.

Seluruh fitur pendukung dapat diakses setelah pengguna melakukan login pada aplikasi. Menu fitur terdapat dalam dashboard sehingga semua aktor dapat mengakses fitur dashboard. Pada dashboard, selain terdapat shortcut menu ke fitur lain, juga terdapat informasi terbaru pada antrian yang sedang terjadi. Sehingga semua aktor dapat melihat dan memantau jalannya antrian dan dapat memanfaatkan waktu yang ada.

Fitur rawat inap digunakan untuk pemesanan ruangan rawat inap. Jika list ruangan dipilih akan tampil detail informasi ruangan dan harga ruangan. Jika ingin melakukan pemesanan maka tekan tombol pesan dan pilih tanggal yang diinginkan. Fitur ini mirip dengan fitur pendaftaran antrian namun tanpa adanya list antrian, karena satu ruangan hanya untuk satu pemesan.

Fitur chat digunakan untuk fasilitas percakapan antar pengguna aplikasi. Bentuk chat adalah group aktif, dimana seluruh pengguna akan masuk kedalam satu chat box. Dengan terbukanya fitur chat untuk semua aktor, maka fitur ini dapat digunakan untuk konsultasi langsung dengan dokter, komplain dengan staff, atau komunikasi dengan sesama pasien selama menunggu antrian.

Fitur map digunakan oleh pasien untuk melihat posisi atau mengetahui arah jalan menuju poliklinik yang dituju. Fitur map menggunakan teknologi dari Google Map API dengan sedikit perubahan desain pada form pencarian. Fitur dokter ditujukan untuk pasien, agar pasien mengetahui siapa saja dokter yang terhubung dengan aplikasi antrian.

Fitur report berisi mengenai riwayat kegiatan yang dilakukan pasien pada aplikasi, mencakup pendaftaran antrian atau pemesanan kamar. Untuk fitur nota digunakan untuk melihat biaya yang harus dibayarkan pada pihak poliklinik.

Fitur pengumuman dan informasi digunakan untuk menyebarkan informasi pada seluruh aktor. Pengumuman lebih kepada informasi dengan urgensi tinggi untuk segera dibaca. Info lebih kepada informasi umum atau share pengetahuan dan memiliki urgensi rendah untuk dibaca.

\section{CONCEPTUAL DATA MODEL}

Conceptual Data Model (CDM) digunakan untuk merepresentasikan relasi antar tabel pada sebuah model database. Gambar 6 menunjukkan hubungan seluruh tabel pada database. Terdapat 13 tabel pada database aplikasi antrian mobile. Database diakses baik melalui aplikasi maupun CMS website.

\section{HASIL APLIKASI MOBILE}

Aplikasi mobile fokus kepada fungsi yang ditawarkan sehingga untuk tampilan menggunakan design standart aplikasi. Login aplikasi menggunakan dua form untuk memasukkan username dan password seperti Gambar 7(a), kemudian tombol login untuk mengirimkan data dan 
melakukan pengecekan kepada sistem. Jika data tidak sesuai akan tampil peringatan, namun jika data telah sesuai maka akan diteruskan ke halaman dashboard (Gambar 7(b)). Tujuan awal dashboard adalah untuk mempermudah user untuk memilih menu yang tesedia pada aplikasi.

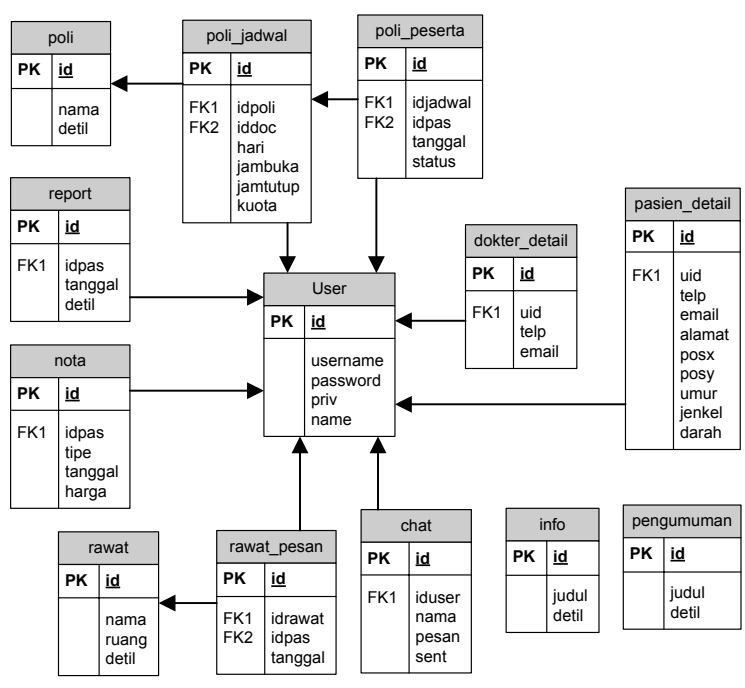

Gambar 6. Conceptual Data Model dari aplikasi yang diusulkan.

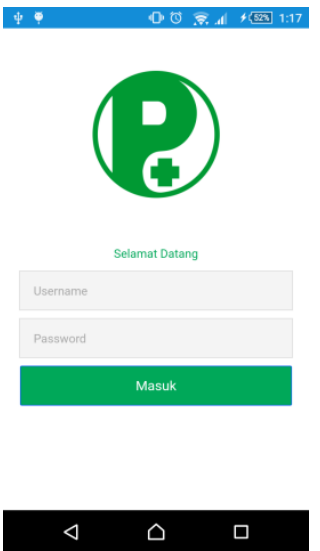

(a)

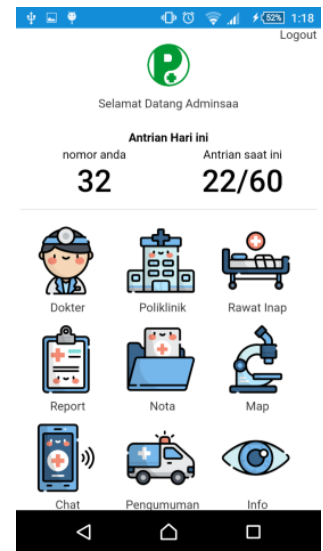

(b)
Gambar 7 (a). Tampilan Login Aplikasi, (b). Tampilan dasboard.

\subsection{Poliklinik}

Aplikasi poliklinik diawali dengan tampilan list dari poliklinik yang digunakan untuk mempermudah user memilih poliklinik yang akan dituju (Gambar 8). Pada list terdapat nama poliklinik dan keterangan singkat mengenai poliklinik tersebut. Untuk foto avatar dapat diganti dengan logo atau foto poliklinik, namun saat ini foto maupun logo poliklinik masih belum diperoleh sehingga menggunakan Gambar default sistem terlebih dahulu.

Jika list poliklinik di klik, maka tampilan akan berubah dan diarahkan menuju detail informasi poliklinik (Gambar 9). Pada halaman ini terdapat penjelasan yang lebih terperinci mengenai informasi poliklinik. Pada bagian atas kanan terdapat tombol jadwal yang digunakan untuk melihat jadwal dari poliklinik yang bersangkutan.

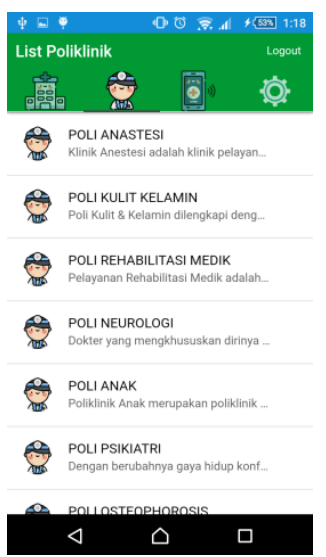

Gambar 8. Tampilan daftar poliklinik.

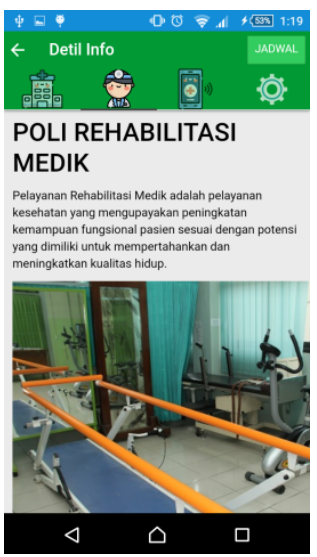

Gambar 9. Detail Infromasi Poliklinik

Pada halaman jadwal terdapat list jadwal yang merepresentasikan jadwal harian dalam seminggu. Jadwal berisi nama dokter, hari dan jam pelaksanaan praktek poliklinik terkait. Pada halaman jadwal juga terdapat form untuk mengisi tanggal, guna untuk mencari jadwal pada tanggal yang diinginkan sesuai hari pada list jadwal yang ada. Sehingga disarankan jika ingin memasukkan tanggal maka diperlukan untuk melihat hari apa saja poliklinik terkait sedang melakukan praktek. Misal jika praktek buka pada hari senin, maka pilihlah tanggal yang bertepatan pada hari senin, misal 5 Juni 2018.

Jika tanggal yang dimasukkan sesuai dengan jadwal, maka akan ditampilkan list jadwal sesuai pada tanggal yang dipilih (Gambar 10(a)). Tampilan list memang hampir mirip dengan list jadwal mingguan, namun terdapat tambahan yaitu tombol lihat antrian. Jika tombol antrian di klik maka akan diarahkan menuju halaman antrian.

Pada halaman list antrian (Gambar 10(b)) akan ditampilkan siapa saja yang pernah melakukan pemesanan antrian pada jadwal yang dipilih. List antrian yang ditampilkan hanyalah username pasien dan nomor antrian yang diperoleh. Untuk melakukan 
pemesanan dapat dengan mengklik tombol Pesan Poliklinik yang terdapat pada bagian atas list antrian. Jika antrian telah memenuhi kuota, maka terdapat peringatan untuk mencoba jadwal lain, namun jika kuota masih mencukupi, maka nama user akan ditampilkan pada list antrian dan dapat melakukan layanan pengobatan pada hari yang telah ditentukan.

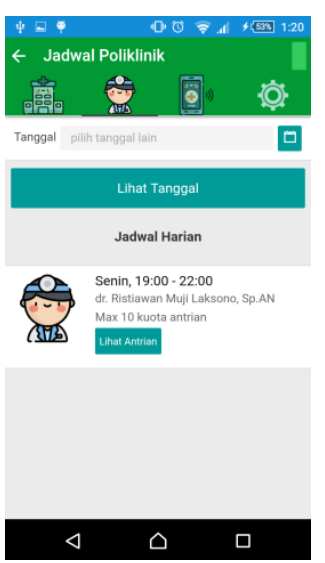

(a)

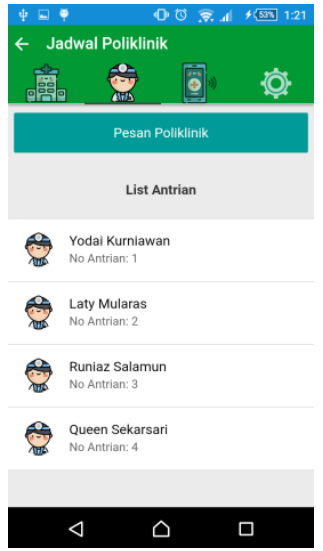

(b)
Gambar 10. (a) List Jadwal, (b) List Antrian

\subsection{Sistem Pendukung}

Selain antrian poliklinik, sistem juga menyediakan fitur untuk memesan ruangan rawat inap. Jika menu rawat inap dipilih, maka akan diarahkan ke halaman list ruangan rawat inap (Gambar 11(a)).

Pada list ruangan terdapat informasi mengenai nama dan keterangan singkat ruangan, juga terdapat logo atau foto ruangan. Jika salah satu list dipilh, maka akan menampilkan detil informasi dari ruangan rawat inap yang dipilih (Gambar 11(b)). Pada bagian pojok kanan atas, terdapat tombol untuk melakukan pemesanan. Sistemnya hampir sama dengan pendaftaran antrian. Lalu untuk menunjang informasi mengenai dokter yang terhubung dengan informasi, maka dibuatlah halaman list dokter (Gambar 12(a)) yang dapat digunakan user.

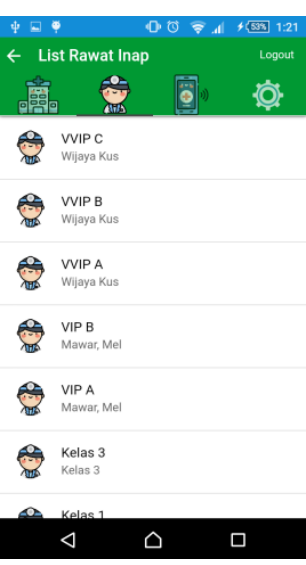

(a)

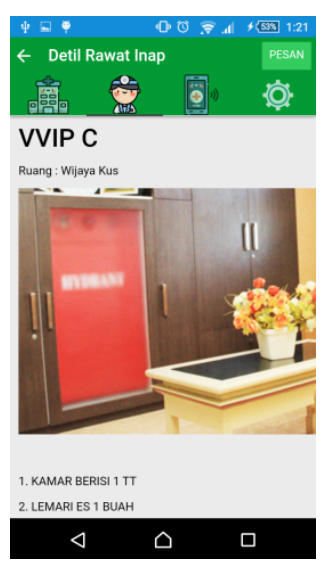

(b)
Gambar 11. (a) List Ruangan, (b) Detail Ruangan Rawat Inap

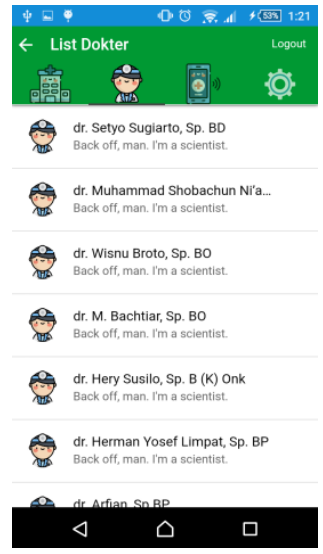

(a)

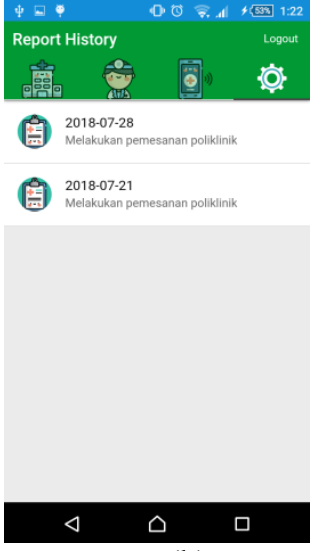

(b)
Gambar 12. (a) List Dokter, (b) Riwayat Pasien

Halaman riwayat pasien (Gambar 12(b)) berfungsi untuk menyimpan aktifitas pasien pada aplikasi antrian poliklinik. Aktifitas ini meliputi pendaftaran antrian dan pemesanan ruang rawat inap. Riwayat dapat digunakan untuk melihat apa saja yang telah dipesan oleh pasien, atau untuk mengingat kembali penyakit apa yang pernah dialami oleh pasien dan kapan.

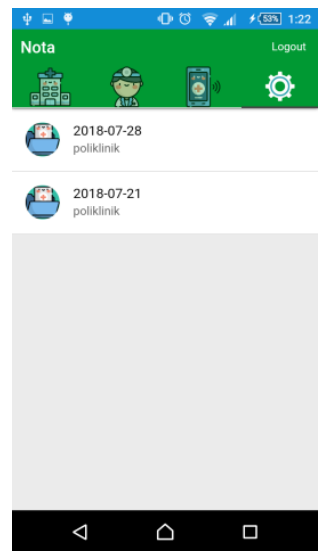

(a)

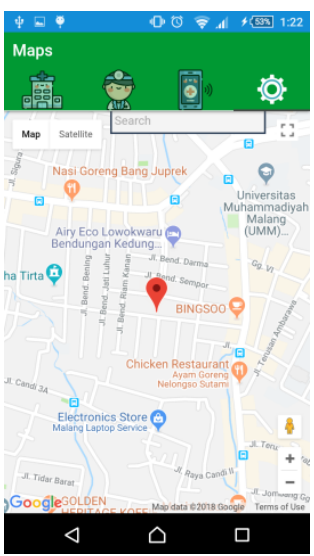

(b)
Gambar 13. (a) List Biaya, (b) Map Poliklinik

Halaman List biaya (Gambar 13(a)) digunakan untuk melihat biaya apa yang pernah ditanggung dan berapa besar biaya yang harus dibayarkan. Besarnya biaya dapat secara otomatis diberikan oleh sistem, namun juga dapat diatur pada website CMS.

Halaman map (Gambar 13(b)) menggunakan API dari google map. Halaman ini berfungsi untuk informasi lokasi poliklinik yang diinginkan. Terdapat form pencarian untuk mempermudah pencarian lokasi.

Halaman Chat (Gambar 14(a)) digunakan melakukan percakapan baik antar pasien maupun percakapan dengan dokter yang sedang aktif. Chat dapat digunakan untuk berkonsultasi dengan dokter maupun staff saat melakukan antrian maupun diluar antrian. Chat juga dapat digunakan untuk mengisi waktu luang saat antrian dengan cara berkomunikasi dengan pasien lainnya. 


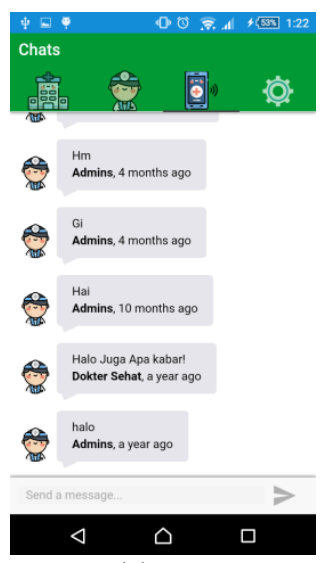

(a)

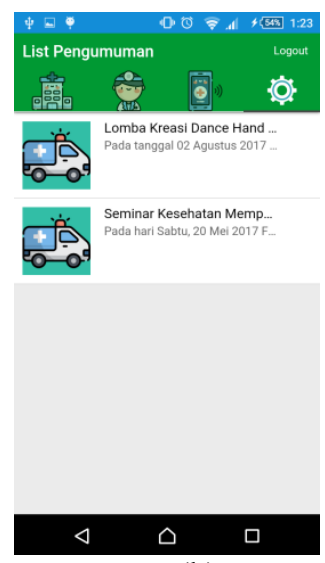

(b)
Gambar 14. (a) Chat, (b) Pengumuman

Gambar 14(b) merupakan halaman pengumuman dan informasi, keduanya memiliki bentuk layout yang sama. Fungsi pengumuman adalah menginformasikan mengenai keadaan atau situasi yang ada pada poliklinik terkait. Bersifat khusus dan memiliki urgensi, sehingga setiap adanya pengumuman baru diperlukan notifikasi agar pasien dapat cepat mengetahui pengumuman yang ada. Sedangakan informasi lebih bersifat umum dan urgensi nya rendah. Digunakan untuk share informasi kesehatan dari pihak rumah sakit kepada pasien.

\section{HASIL CMS WEBSITE}

Pada login CMS (Gambar 15) terdapat username dan password. Akun yang digunakan untuk login pada CMS sama dengan login pada aplikasi, namun pada CMS dibatasi hanya untuk akun dengan hak akses staff atau admin. Setelah login akan masuk pada halaman dashboard.

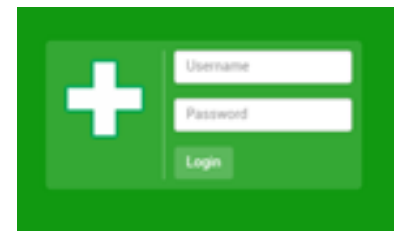

Gambar 15. Tampilan Login CMS

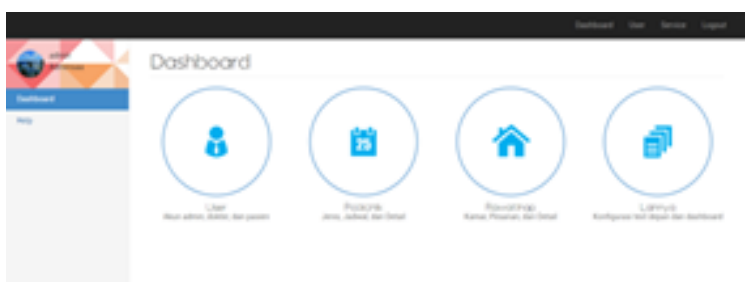

Gambar 16. Tampilan Dashboard CMS

Dashboard (Gambar 16) dibuat sesuai rancangan yaitu sebagai portal untuk dapat mengakses fitur atau menu lainnya. Namun untuk selanjutnya dashboard juga dapat digunakan sebagai wadah untuk meletakkan data analisa atau infografis.

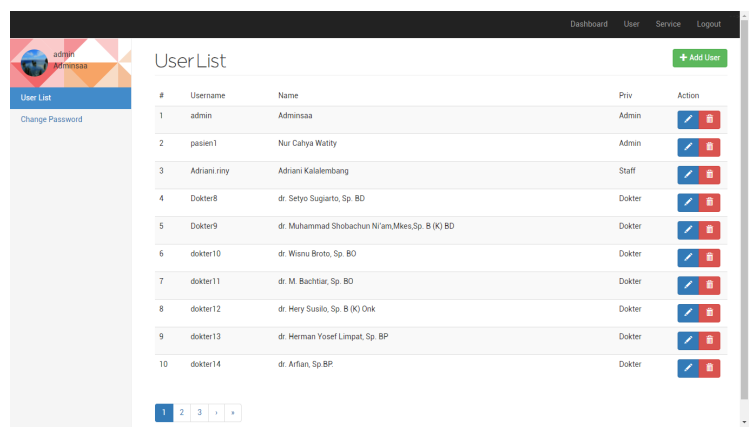

Gambar 17. Tampilan List User

Pada menu user (Gambar 17) terdapat list user dengan informasi username, nama, dan hak akses yang dimiliki. Setiap data yang ditampilkan terdapat tombol untuk mengubah dan menghapus data. Pada atas kanan, terdapat tombol tambah user untuk menambahkan akun baru dengan hak akses, username, password, dan nama baru.

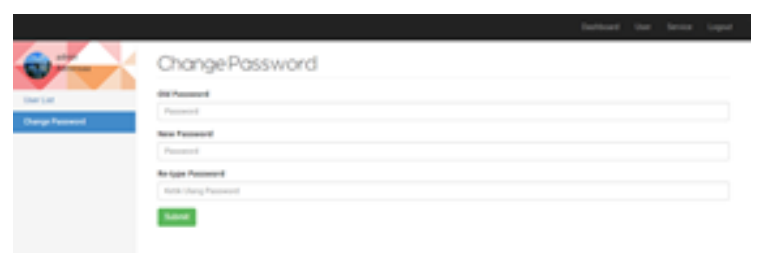

Gambar 18. Tampilan Ubah Password

Ubah password (Gambar 18) digunakan untuk mengubah password pada akun yang sedang digunakan untuk masuk ke dalam Web CMS. Ubah password cukup mudah yaitu dengan memasukkan password baru, password lama, dan mengulangi password baru lagi untuk klarifikasi.

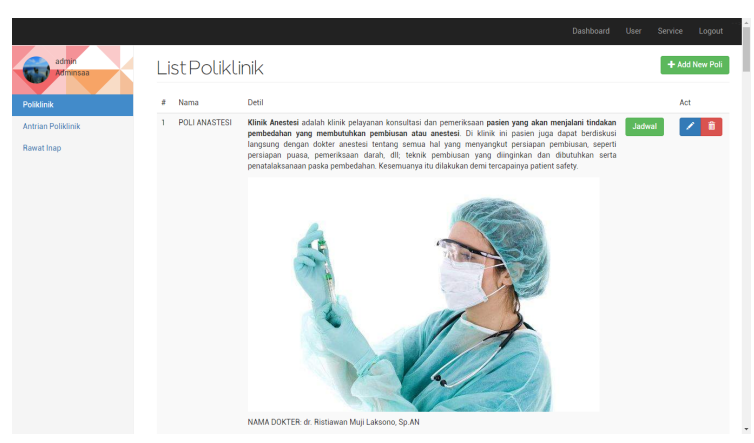

Gambar 19. Tampilan List Poliklinik

Halaman Poliklinik (Gambar 19) berisi mengenai nama setiap poliklinik dan detil informasi didalamnya. Pada bagian awal terdapat tombol tambah data, digunakan untuk menambahkan data poliklinik baru. Pada setiap list poliklinik memiliki tombol untuk mengubah dan menghapus data poliklinik. Dan juga pada setiap list poliklinik terdapat tombol jadwal untuk menambahkan data jadwal poliklinik tersebut secara mingguan. 


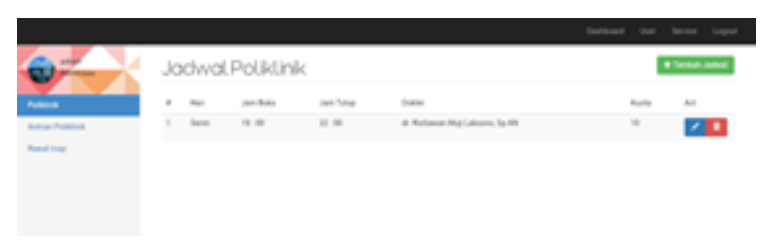

Gambar 20. Tampilan List Jadwal

Sama dengan list lainnya, list jadwal (Gambar 20) memiliki fungsi tambah, edit dan hapus. Data yang digunakan pada perekaman jadwal adalah hari dan jam praktek, dokter yang menangani, dan kuota yang dapat dilayani pada jadwal tersebut.

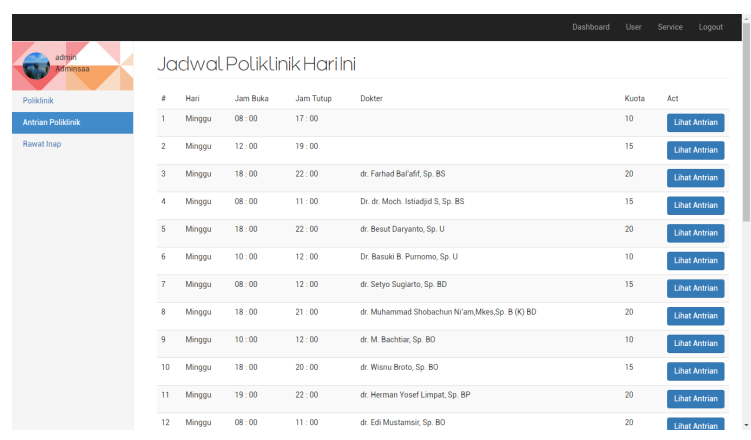

Gambar 21. Tampilan List Jadwal

Pada menu antrian poliklinik (Gambar 21) menampilkan data antrian yang dapat dilayani hari ini. Data pada halaman ini dapat digunakan untuk bantuan pemanggilan antrian saat jadwal sedang berjalan. Pada setiap list jadwal terdapat tombol lihat antrian yang mengarah pada halaman dengan antrian pasien.

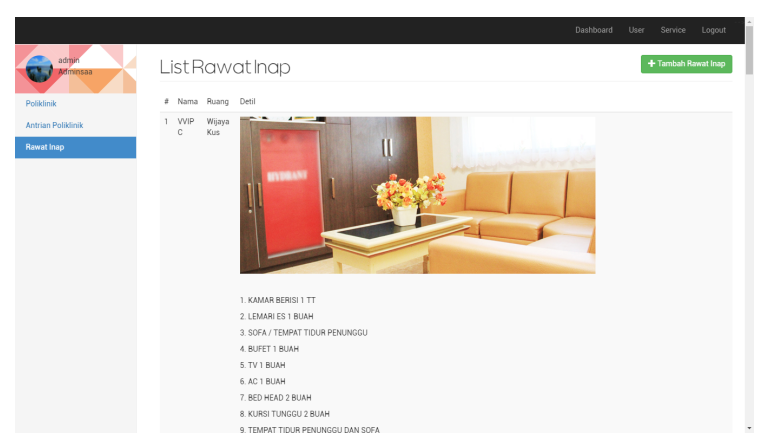

Gambar 22. Tampilan List Rawat Inap

Halaman pada Gambar 22 digunakan untuk mengatur data ruangan rawat inap yang tersedia pada poliklinik. Sama dengan list lainnya, terdapat fungsi penambahan, pengubahan, dan penghapusan data.

\section{PENGUJIAN SISTEM}

\subsection{Pengujian White Box}

White Box Testing adalah metode pengujian software dimana penguji mengenali seluk beluk sistem, perancangan, dan implementasi sistem. Biasanya digunakan untuk unit testing dan berguna pada saat integrasi dengan sistem secara utuh. Fokus dari pengujian yang dilakukan adalah pada fungsi doPesan() yang digunakan untuk pendaftaran antrian poliklinik. Alur pengujian dapat dilihat pada Gambar 23.

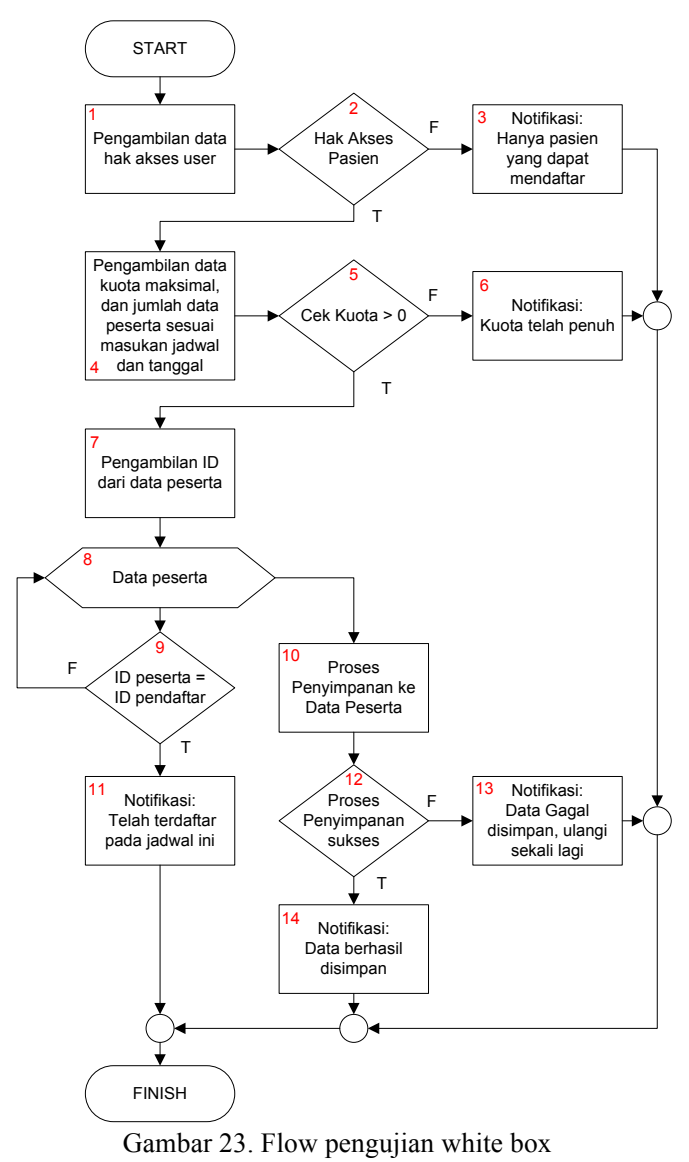

Pengujian fungsional dilakukan pada setiap blok tugas dengan melakukan pengecekan masukan dan keluaran. Sedangkan pada pengujian alur menggunakan rute percabangan pada setiap skenario pemesanan. Setiap rute yang mungkin terjadi akan diuji dan dipastikan hasil keluaran setiap proses.

Dasar Rute Independen:

1. Rute $1: 1-2-3$

2. Rute $2: 1-2-4-5-6$

3. Rute $3: 1-2-4-5-7-8-9-11$

4. Rute $4: 1-2-4-5-7-8-9-10-12-13$

5. Rute $5: 1-2-4-5-7-8-9-10-12-14$

Pada Tabel 1 menunjukkan hasil pengujian white box berikut penjelasan terkait kondisi dan hasil yang diharapkan. Hasil pengujian menunjukkan bahwa setiap alur kemungkinan yang ada telah menghasilkan output yang sesuai dengan harapan. Hal itu menjadikan kemungkinan bagi pengguna melakukan kesalahan dan menemui jalan buntu pada aplikasi telah dapat dihindari. 
Tabel 1. Pengujian Rute

\begin{tabular}{|c|c|c|c|}
\hline Rute & Kondisi & Expected Result & Status \\
\hline 1 & $\begin{array}{l}\text { Hak Akses User } \\
\text { adalah Dokter atau } \\
\text { Staff, bukan Pasien }\end{array}$ & $\begin{array}{l}\text { Berhenti pada } \\
\text { proses } \\
\text { pengecekan hak } \\
\text { akses, dan } \\
\text { menampilkan } \\
\text { pesan hak akses }\end{array}$ & Valid \\
\hline 2 & $\begin{array}{l}\text { Hak akses Pasien dan } \\
\text { kuota pada jadwal } \\
\text { tersebut telah penuh }\end{array}$ & $\begin{array}{l}\text { Berhenti pada } \\
\text { proses } \\
\text { pengecekan } \\
\text { kuota dan } \\
\text { menampilkan } \\
\text { pesan kuota } \\
\text { penuh }\end{array}$ & Valid \\
\hline 3 & $\begin{array}{l}\text { Hak akses Pasien, } \\
\text { terdapat kuota, } \\
\text { namun telah } \\
\text { melakukan } \\
\text { pendaftaran pada } \\
\text { jadwal tersebut }\end{array}$ & $\begin{array}{l}\text { Menghentikan } \\
\text { proses } \\
\text { perulangan } \\
\text { pengecekan } \\
\text { peserta dan } \\
\text { menampilkan } \\
\text { pesan telah } \\
\text { terdaftar }\end{array}$ & Valid \\
\hline 4 & $\begin{array}{l}\text { Hak akses Pasien, } \\
\text { terdapat kuota, belum } \\
\text { melakukan } \\
\text { pendaftaran pada } \\
\text { jadwal tersebut, } \\
\text { namun penyimpanan } \\
\text { data peserta gagal }\end{array}$ & $\begin{array}{l}\text { Menampilkan } \\
\text { pesan gagal } \\
\text { menyimpan data, } \\
\text { mohon ulangi } \\
\text { sekali lagi }\end{array}$ & Valid \\
\hline 5 & $\begin{array}{l}\text { Hak akses Pasien, } \\
\text { terdapat kuota, belum } \\
\text { melakukan } \\
\text { pendaftaran pada } \\
\text { jadwal tersebut, dan } \\
\text { penyimpanan data } \\
\text { peserta sukses }\end{array}$ & $\begin{array}{l}\text { Menampilkan } \\
\text { pesan } \\
\text { pendaftaran } \\
\text { berhasil dan list } \\
\text { data peserta } \\
\text { antrian } \\
\text { diperbarui }\end{array}$ & Valid \\
\hline
\end{tabular}

\subsection{Pengujian Black Box}

Black Box Testing adalah metode pengujian software dimana penguji tidak perlu mengenali seluk beluk sistem, perancangan, dan implementasi sistem. Biasanya digunakan untuk test hasil integrasi dengan sistem secara utuh. Fokus dari pengujian yang dilakukan adalah pada fitur utama yaitu poliklinik.

Tabel 2. Test Case pengujian validasi

\begin{tabular}{|c|c|c|c|}
\hline no & Kasus Uji & Kondisi & Hasil \\
\hline 1 & Login & $\begin{array}{l}\text { User dapat melakukan login } \\
\text { aplikasi dengan menggunakan } \\
\text { username dan password yang } \\
\text { telah diberikan. }\end{array}$ & Valid \\
\hline 2 & $\begin{array}{l}\text { List } \\
\text { Poliklinik }\end{array}$ & $\begin{array}{l}\text { Menampilkan data poliklinik } \\
\text { secara teratur dan sesuai } \\
\text { dengan database baik pada } \\
\text { aplikasi dan cms }\end{array}$ & Valid \\
\hline 3 & $\begin{array}{l}\text { CRUD } \\
\text { Poliklinik }\end{array}$ & $\begin{array}{l}\text { Akses penambahan, } \\
\text { pengubahan, dan } \\
\text { penghapusan data pada CMS }\end{array}$ & Valid \\
\hline 4 & $\begin{array}{l}\text { Hak Akses } \\
\text { Pendaftaran } \\
\text { Poliklinik }\end{array}$ & $\begin{array}{l}\text { Hanya akun dengan hak akses } \\
\text { pasien yang dapat melakukan } \\
\text { pendaftaran poliklinik. Hak } \\
\text { akses dokter dan staff tidak } \\
\text { dapat melihat tombol pesan. }\end{array}$ & Valid \\
\hline 5 & $\begin{array}{l}\text { List Jadwal } \\
\text { Poliklinik }\end{array}$ & $\begin{array}{l}\text { Menampilkan jadwal } \\
\text { poliklinik sesuai dengan ID } \\
\text { poliklinik yang dipilih pada } \\
\text { list poliklinik. }\end{array}$ & Valid \\
\hline 6 & $\begin{array}{l}\text { Pencarian } \\
\text { Jadwal } \\
\text { Poliklinik }\end{array}$ & $\begin{array}{l}\text { Pencarian sesuai dengan } \\
\text { tanggal dan menampilkan } \\
\text { sesuai hari yang terdapat pada } \\
\text { jadwal }\end{array}$ & Valid \\
\hline
\end{tabular}

\begin{tabular}{llll}
7 & List & $\begin{array}{l}\text { Menampilkan antrian sesuai } \\
\text { dengan tanggal dan ID } \\
\text { poliklinik yang dipilih } \\
\text { Memproses pilihan }\end{array}$ & Valid \\
8 & $\begin{array}{l}\text { Pendaftaran } \\
\text { Poliklinik }\end{array}$ & $\begin{array}{l}\text { Vendaftaran pengguna saat } \\
\text { pengguna menekan tombol } \\
\text { pesan } \\
\text { Menampilkan Nomor Antrian } \\
\text { user dan nomor yang sedang } \\
\text { berjalan }\end{array}$ & Valid \\
& $\begin{array}{l}\text { Info } \\
\text { Antrian } \\
\text { Live }\end{array}$ & & \\
\hline
\end{tabular}

Pada Tabel 2 menunjukkan hasil pengujian Black box. Hasil pengujian menunjukkan bahwa sistem telah memenuhi semua aspek kasus uji. Sehingga setiap fungsi dapat dipastikan akan tidak mengalami kesalahan saat digunakan.

\subsection{Usability Testing}

Usability Testing menggunakan 10 heuristic evaliation yang dikembangkan oleh Jacob Nielsen. Evaluasi heuristik adalah metode pengujian untuk perangkat lunak komputer yang membantu mengidentifikasi masalah kegunaan dalam desain antarmuka pengguna. Metode ini secara khusus melibatkan evaluasi antarmuka dan menilai kepatuhannya dengan prinsip-prinsip usability.

Tabel 3. Heuristik Testing

\begin{tabular}{|c|c|c|c|}
\hline no & Prinsip & Ada? & Bagaimana? \\
\hline 1 & $\begin{array}{l}\text { Visibility Of } \\
\text { System Status }\end{array}$ & Tidak & $\begin{array}{l}\text { Sistem hanya menggunakan } \\
\text { loading screen saat } \\
\text { melakukan koneksi ke } \\
\text { database }\end{array}$ \\
\hline 2 & $\begin{array}{l}\text { Match between } \\
\text { system and real- } \\
\text { world }\end{array}$ & $\mathrm{Ya}$ & $\begin{array}{l}\text { Menggunakan bahasa } \\
\text { natural yang mudah } \\
\text { dipahami oleh masyarakat } \\
\text { umum }\end{array}$ \\
\hline 3 & $\begin{array}{l}\text { User Control } \\
\text { And Freedom }\end{array}$ & Tidak & $\begin{array}{l}\text { Belum diimplementasikan } \\
\text { untuk pembatalan } \\
\text { pendaftaran antrian, namun } \\
\text { telah diberikan konfirmasi } \\
\text { box sebelum pendaftaran }\end{array}$ \\
\hline 4 & $\begin{array}{l}\text { Consistency and } \\
\text { Standart }\end{array}$ & $\mathrm{Ya}$ & $\begin{array}{l}\text { Terdapat pada standarisasi } \\
\text { penggunaan warna untuk } \\
\text { teks normal, teks link, judul, } \\
\text { tombol utama, dan tombol } \\
\text { sekunder. }\end{array}$ \\
\hline 5 & Error Prevention & Ya & $\begin{array}{l}\text { Pada setiap input } \\
\text { menggunakan penyesuaian } \\
\text { tipe masukan, dan terdapat } \\
\text { pengecekan sebelum proses } \\
\text { ke database dilakukan }\end{array}$ \\
\hline 6 & $\begin{array}{l}\text { Recognition } \\
\text { rather than } \\
\text { Recall }\end{array}$ & Ya & $\begin{array}{l}\text { Icon dasar dan icon menu } \\
\text { telah disesuaikan dengan } \\
\text { fungsinya. Misal delete, } \\
\text { cancel, close, dokter, report. }\end{array}$ \\
\hline 7 & $\begin{array}{l}\text { Flexibiity and } \\
\text { efficiency of use }\end{array}$ & Ya & $\begin{array}{l}\text { Terdapat History } \\
\text { pendaftaran untuk akses } \\
\text { cepat ke layanaan yang } \\
\text { pernah digunakan }\end{array}$ \\
\hline 8 & $\begin{array}{l}\text { Aesthethic and } \\
\text { minimalis design }\end{array}$ & Ya & $\begin{array}{l}\text { Menggunakan warna dasar } \\
\text { putih dengan warna utama } \\
\text { hijau.. dan penggunaan } \\
\text { white space tiap element. }\end{array}$ \\
\hline 9 & $\begin{array}{l}\text { Help users } \\
\text { recognize, } \\
\text { diagnose, and } \\
\text { recover from } \\
\text { errors }\end{array}$ & $\mathrm{Ya}$ & $\begin{array}{l}\text { Setiap interaksi yang } \\
\text { dilakukan user, jika terjadi } \\
\text { kesalahan atau gagal, maka } \\
\text { sistem akan menampilkan } \\
\text { pop up pemberitahuan untuk } \\
\text { memberikan saran pada user }\end{array}$ \\
\hline
\end{tabular}




\begin{tabular}{lll} 
& & $\begin{array}{l}\text { mengenai apa yang harus } \\
\text { dilakukan. Contoh pada } \\
\text { login, jika salah disarankan } \\
\text { melakukan pengecekan } \\
\end{array}$ \\
& ulang. \\
Help and & Ya \\
Tecumentation & & $\begin{array}{l}\text { Terdapat menu bantuan } \\
\text { pada setting sistem }\end{array}$ \\
\hline
\end{tabular}

Pada Tabel 3 menunjukkan hasil pengujian Usability. Hasil pengujian menunjukkan bahwa $80 \%$ dari prinsip usability telah di implementasikan. Hasil pengujian cukup dapat memberikan kenyamanan penggunaan pada pengguna.

\section{KESIMPUAN DAN SARAN}

Penelitian rancang bangun aplikasi antrian poliklinik dapat digunakan untuk mempermudah calon pasien poliklinik untuk melakukan pendaftaran tanpa perlu mendatangi ataupun menghubungi pihak poliklinik. Sistem ini juga memberikan informasi antrian secara langsung sehingga calon pasien dapat mengawasi jalannya antrian tanpa perlu berada di lokasi antrian.

Pengujian menunjukkan bahwa hasil dari rancangan yang diajukan dapat digunakan dengan baik. Kemungkinan kesalahan yang terjadi pada alur sistem telah diminimalisir bahkan dihilangkan. Penyesuaian sistem dengan prinsip heuristik usability diharapkan mampu meningkatkan kenyamanan penggunaan aplikasi. Keseluruhan sistem telah dapat digunakan dalam implementasi pada poliklinik.

\section{DAFTAR PUSTAKA}

ABIDIN, R. 2016. Ionic Framework - Tool Untuk Membuat Aplikasi Mobile Lintas Platform. Retrieved June 21, 2018, from https://teknojurnal.com/ionic-framework-tooluntuk-membuat-aplikasi-mobile-lintasplatform/

BAMBANG S. 2017. Aplikasi Antrian Pendaftaran Pasien Berbasis Desktop. Universitas Muhammadiyah Surakarta.

BUSTANI, N. M., RATTU, A. J., \& SAERANG, J. S. M. 2015. Analisis Lama Waktu Tunggu Pelayanan Pasien Rawat Propinsi Sulawesi Utara, 3. STIKes Surya Mitra Husada

D. V. CHANDRAN, DIYYA P., POOJA G., ARATI G. 2017. Multiple Queue Management With Real Time Tracking For OPD Scheduling In Hospitals. International Journal for Research in Engineering Application \& Management (IJREAM), Vol-03, Issue 02, Apr 2017.

IBRAHIM, B. 2017. Modeling Hospital Triage Queuing System. Global Journal of Researches in Engineering, Volume XVII Issue I Version I.

KUNDANG K. J. 2012. Analisis Dan Perancangan Sistem Informasi Antrian Pada PT. Bank
Rakyat Indonesia (PERSERO) TBK. Unit Pasar Timbul. Forum Ilmiah, Volume 9 Nomer 3, September 2012.

LAELIYAH, N., \& SUBEKTI, H. 2017. Waktu Tunggu Pelayanan Rawat Jalan dengan Kepuasan Pasien Terhadap Pelayanan di Rawat Jalan RSUD Kabupaten Indramayu. Jurnal Kesehatan Vokasional, 1(2), 102-112. https://doi.org/10.22146/JKESVO.27576

SAEFULLAH, ASEP, DIYAH A, ANDY R. 2014. Sistem Notifikasi Antrian Berbasis Android. Journal Creative Communication and Innovative Technology (CCIT) STMIK Raharja.

SUKMA, B. A., TENGKU, A. R., ROHMAT, T. 2015. Perancangan dan Implementasi Sistem Antrian Untuk Pasien Pada Dokter Umum Berbasis Android dan SMS Gateway. Jurnal Elektro Telekomunikasi Terapan Juli 2015.

SWAPNIL J., MANJUSHA T., 2018. Survey Paper on Patient Treatment Time Prediction in Hospital Queuing Management. International Journal of Engineering Science and Computing, Volume 8 Issue No.1.

SYED S. S. D., UBEDUR R., MAID S.C. 2018. GSM Based Queue Management Device for OPD. International Research Journal of Engineering and Technology, Volume 5 No 4, Apr-2018

TORRY, KOESWO, M., \& SUJIANTO. 2016. Faktor yang Mempengaruhi Waktu Tunggu Pelayanan Kesehatan kaitannya dengan Kepuasan Pasien Rawat Jalan Klinik penyakit dalam RSUD Dr . Iskak Tulungagung Factors Influencing Service Waiting Times in Relation to Internist Clinic Outpatient' s Satisfaction, 29(3), 252-257.

WIYATA. 2016. Rancang Bangun Sistem Informasi Honorarium Mengajar Dosen. Jurnal Teknologi Informasi Dan Ilmu Komputer (JTIIK), Vol. 3, No. 1, hlm. 35-42

XIA H., SEAN B., BRUCE G., 2018. Applying queueing theory to the study of emergency department operations: a survey and a discussion of comparable simulation studies. International Transactions In Operational Research. Intl. Trans. In Op. Res. 25 (2018) 749.

YEO S., SURESH S., SITI N. B. S. 2013. Application of Smart Technologies for Mobile Patient Appointment System. International Journal of Advanced Trends in Computer Science and Engineering, Volume 2, No.4, July - August 2013 